\title{
The State of the Art of Materials Management Research in the Construction Industry
}

\author{
Ngor K. Koriom ${ }^{1}$, Juliana Brahim ${ }^{1}$, Ideris Zakaria ${ }^{1}$ A.B.M Amrul Kaish ${ }^{1}$ and Manal Mohsen ${ }^{1}$ \\ ${ }^{1}$ Faculty of Engineering, Technology and Infrastructure, Infrastructure University Kuala Lumpur (IUKL), 43000 Kajang, Selangor \\ Malaysia.
}

\begin{abstract}
Materials management is a vital element in managing projects as materials contribute more than $60 \%$ of the total project cost. It also plays a key role because the success of every construction project relies heavily on having materials on time and at a reasonable cost. Thus, it affects the overall project performance. Despite the importance of materials management for construction projects, construction contractors are still suffering from the loss of productivity, project delay and cost overruns due to the absence of proper implementation of materials management. Therefore, the aim of this paper is to review the state of the art of materials management research in the construction industry. A literature review from books, journal articles and conferences papers related to this topic was carried out. Findings show that previous research related to materials management studies were focused more on large construction contractors while small and medium contractors have received little attention. Hence, a study that focuses on the small and medium contractors is needed as this group undertakes more than $90 \%$ of the activities in the Malaysian construction industry.
\end{abstract}

\section{Introduction}

The construction industry plays a vital role in Malaysia's development. It contributes significantly to the national economic growth, provides job opportunities directly and indirectly and improves the quality of life by providing the basic infrastructure. In addition, the construction industry is a valuable customer for other industries including manufacturing and services [1]-[2]. However, the issue of a lack of management has become the main concern of the construction industry [3], especially issues related to materials management. This is because construction materials represent one of the critical components in the construction industry [4]. Past literature shows that construction materials account for about $50-60 \%$ of a construction project's cost [5] and have an $80 \%$ impact on a project's cost and schedule [6]. Thus, effective materials management practices could affect the productivity and profitability of construction projects. Past studies have also proven that effective materials management could potentially increase productivity by $8 \%$, reduce crew idle time at the construction sites, save about $1.8 \%$ of materials cost and eventually reduce the cost of labour by $6 \%$ [7], [8], due to materials being available at the site at the right time prior to the start of the work and in the right quality and at the most reasonable cost possible. Therefore, the effective management of materials would support improvements in work planning [9] to the significant benefit of the construction industry. However, the literature emphasizes that construction contractors are suffering from loss of productivity, project delay and cost overruns due to the absence of proper implementation of materials management. Hence, previous studies have been extensively conducted on improving materials management in the construction industry. Nevertheless, issues have still materialized and contractors are still unable to get the maximum benefit from materials management implementation. Therefore, the primary purpose of this paper is to review the stateof-the-art of materials management research in the construction industry.

\section{Literature Review on Materials Management}

\subsection{Material management definition}

Numerous materials management definitions were found in the literature. For instance, Caldas et al. [6] define materials management as "an integrated process that consists of the people, organisations, technology, and procedures used to effectively identify, quantify, acquire, expedite, inspect, transport, receive, store, and preserve the materials, equipment, and associated information across the life cycle of a capital project".

\footnotetext{
* Corresponding author: Ngorgracethiik@Gmail.com
} 
Meanwhile, [10] defines materials management as a system for planning and controlling all necessary efforts to make certain that the right quality and quantity of materials and equipment are appropriately specified in a timely manner, obtained at a reasonable cost and available when needed. On the other hand, the Construction Industry Institute (CII) defines materials management as planning and controlling of all material and equipment so that they are requested in advance, obtained at a reasonable cost and available when needed.

In conclusion, materials management could be defined according to the three phases of the construction project (prior to the project, during the project and for post-project execution). Prior to the project execution, materials management could be a distinct process of integration, identification and coordination of materials and equipment into the bill of quantity. While the project execution plan refers to a process of purchasing, expediting, inspecting, transporting and storing of materials and equipment identified in the materials management plan. The post-project materials management could be related to the process of assessing and evaluating the implementation of the material plan identified in phase one.

\subsection{Material Management Processes in a Construction Project}

Materials management processes in construction projects consist of planning, procurement, handling, stocking and waste control, and the logistics surrounding materials used in projects [11]. Figure 1 illustrates the six (6) different stages of the materials management process in the construction industry including the connection and amalgamation of the activities in each phase. The decisions taken at each stage of the process will definitely affect the other states of materials management. Therefore, successful implementation of a materials management system needs to consider the different decisions made at various phases of the materials management process.

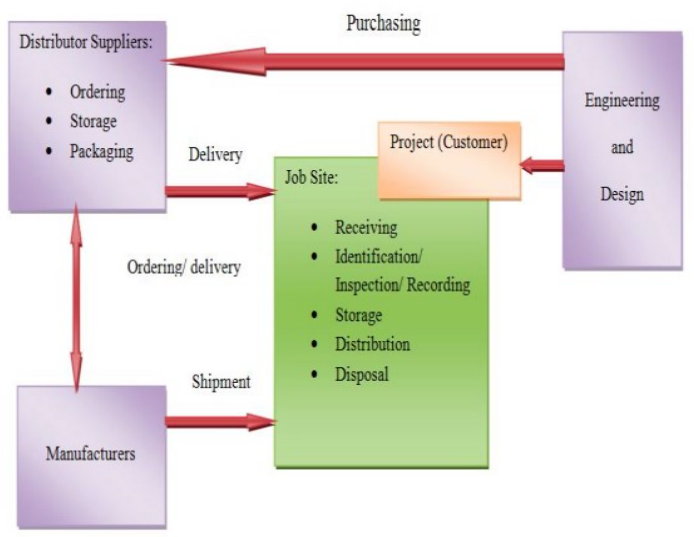

Fig. 1: Typical Materials Management in Construction. Source: [12]

\subsection{Materials Management in the Construction Industry}

[13] conducted a study on materials management practices in a fast developing economy. The aims of the study were to investigate the materials management approach of local contractors and identify problems facing materials management implementation. A questionnaire survey was served across Malaysia. The findings revealed that:

- The materials preparation schedule is based on the use of the conventional approach to preparation,

- A lack of a systematic method to record and control materials during the construction phase with the manual method being preferred in the local industry, and

- Delays in materials delivery by the vendor are the main cause of the material shortages experienced by contractors.

Furthermore, a materials control flowchart was developed to identify all the activities involved in managing materials.

[14] studied improper materials handling at the construction site and its effect on productivity. The aims of the research were to develop an efficient materials management model that could minimize inefficiencies in materials handling activities to improve on-site labour productivity. Data were collected using a questionnaire survey and interviews for understanding the current material practices and the root causes of improper material handling. Findings showed that three (3) main reasons cause improper material handling: schedule issues (including activity schedules and crane schedules), materials storage/positioning issues and contractor-supplier coordination issues. The output of the research was a web-based model for productivity improvement for the large construction contractors. As a result, 20\% labour improvement was achieved through the identification and elimination of ineffective materials handling activities at the site.

[15] researched onsite inventory tracking in the Malaysian construction industry. The study investigated the current materials tracking practices in the industry and how it could be improved. Findings reveal that potential improvement is possible in inventory tracking when contractors implement RFID technology. As an output, [15] has developed an on-site material tracking framework for the inventory management process which consists of seven components namely: manufacturing, materials delivery, materials arrival, materials storage, materials use, an on-site control centre and report generation.

[5] employed a questionnaire survey and interview techniques to find out the current materials management practices in large construction industries in the United Kingdom. Findings revealed that the main contractors are having materials management personnel and a department responsible for materials management. The majority of contractors monitor the material usage, plan and material purchases and forecast the materials needed on-site. In addition, large contractors conduct the on-site material check and have a proper quality assurance 
scheme. The popular policy used in the ordering and storage of materials is scheduling materials. As an output, the study proposed a materials management system composed of:

- Activities in construction work which will be modelled on a "work breakdown structure" using object-oriented programming. In this case, detailed information about the required materials will be presented.

- The timing of activities and sub-activities in the "work breakdown structure" and the materials needed for the planning period.

- A stock information system which keeps track of materials used, materials in the storage yard and the level of the safety stock.

- A site layout model that shows where activities should be carried out, the travelling route of materials and the handling method needed.

- Forecasts of materials needed and lead time needed. Reporting facilities on the progress of the work, the materials used and the materials needed.

[16] reviewed the materials management practices and the possible improvements that could be made to increase the project performance. However, findings showed that the construction contractor's use of information communication technology for managing materials is poor and that they are relying heavily on the conventional method which affects the project timeline. To overcome the problem, [17] developed a prototype system that integrates and amalgamates all the available software and hardware such as MS Access (database system), MS Project (resource modelling) and RFID (automated materials tracking) to provide the mechanisms for integrating materials management and resource modelling in the construction industry. As a result, the prototype system was proven to improve materials management in construction projects.

A recent study conducted by [6] investigated the current materials management practices in large North American construction companies. The aims of the study were to identify materials management techniques that reflect the current and emerging practices related to materials management in the industry. A questionnaire was served in two phases and interviews took place. The findings of the study identified a number of materials management practices. In addition, the study clearly noticed a great improvement in materials management practices related to the implementation of information technology and the integration of the quality process in the early planning stage of materials requesting. In order for contractors to be more effective in materials management, [6] suggested that:

- Early project planning should include global market studies that not only identify the least expensive sources of equipment and materials of verifiable quality but also consider the costs and complexity of global logistics in more detail than has been customary in the early planning stages.

- Project planning should include the emerging topic of sustainability, and contractors should develop their ability to contribute to owners' requirements in this area.

- The refinement and standardization of interfacing among Information Technology (IT) systems offer great potential for improvement. Materials managers should influence IT system selection and integration during pre-project planning. Training programmes should be better integrated into project schedules such that improvements in the use of materials management IT systems occur continuously.

- Managers should proactively address quality issues in global sourcing by planning to import from qualified suppliers or developing the local supply base to achieve desired quality standards before the start of a project.

[4] assessed the materials management on building construction sites in Nigeria. The aims were to determine the method of material procurement practices on a construction site and suggest measures to improve their effectiveness. A structured survey questionnaire was used with 40 respondents. The findings show that procurement of materials based on a requisition from the site is more common with the contractors and is the best practice to achieve effective materials management for construction sites. In addition, the research identifies the measures for effective materials management on building construction sites such as the employment of skilled labourers and operators, training of both management and other staff, employment of storekeepers and security personnel; ensuring that procurement requisitions specify quality, quantity and delivery time; ensuring proper planning and scheduling of building works, introducing materials management at the design stage and consideration of weather conditions.

[17] reviewed materials management in the construction industry aiming to identify the influential factors which affect it. A massive literature review has been undertaken which resulted in the identification of 47 factors. The factors have been classified into 8 groups namely: (1) site conditions; (2) planning and handling on-site; (3) management; (4) materials; (5) supplier and manufacturer default; (6) transportation; (7) contractual; and (8) governmental interference. The findings revealed that the highest number of influential factors is under the 'management' group with 15. The study further developed a model to assist the construction players and contractors to implement materials management.

[18] explored the factors affecting materials management in the construction industry from the perspective of large, medium and small construction contractors. The findings show that factors are different within the three categories, due to the contractor's capability, i.e. factors affecting materials management in large firms are:

- Delay due to the rejection of materials by the quality control team,

- Transportation problems,

- Seasonal problems

While the factors in small and medium companies are:

- Delay due to the rejection of materials by the quality control team,

- Transportation problems,

- Seasonal problems,

- Labour strikes, 
- Communication problems,

- Hikes in material prices,

- Inadequate materials management,

- Improper material handling.

[19] studied the techniques to measure the effectiveness of materials management in the industrial construction industry and to facilitate their implementation. The paper developed a classification scheme consisting of 35 effectiveness measures obtained through site visits and other sources. The list consisted of six categories which applied to facilitate the implementation of effective materials management: accuracy, quality, quantity, cost, timeliness and availability. In continuation, Al-Khalil [15] applied Plemmons' [19] findings by assessing the effectiveness of 17 industrial construction projects using his criteria [20]. The findings revealed that most of the projects have been implementing effective materials management and the criteria tend to be achievable in the large construction firms.

[12] investigated the challenge affecting the effectiveness of materials management in the Malaysian construction industry. A questionnaire survey identified 11 factors that affect materials management in the local industry. Among these factors are, 'capable personnel', 'using manual processes' and 'well-designed construction materials' were ranked as top challenges. Meanwhile, 'planning and controlling knowledge about the materials' and 'cooperation among workers' and 'the site' have less effect on materials management.

[21] investigated the materials management practices

\section{Results and Discussion}

Based on the extensive literature review, ten (10) research publications related to materials management in the Somalian construction industry. The absence of an effective materials management system in Somalia was the motivation behind conducting the research, in order to enhance materials management practices on construction sites. Data were collected using a questionnaire survey and the findings prove that the majority of organizations procure materials to the site without acknowledgement of engineers. However, contractors showed a willingness to use advanced computerized systems in managing materials, hence, the study recommended the utilization of computerized construction materials management systems to reduce the effort and time spent managing materials.

\section{Methodology}

The methodology is the theory of how research should be undertaken, including the theoretical and philosophical assumptions upon which research is based and the implications of these for the method or methods adopted. [22]. To meet the objective of this paper, an intensive literature review was conducted to explore and discuss the evolution of materials management research in the construction industry. The paper systematically reviewed books and articles published in high-impact journals between the years 1990-2018 to relate the past and the current materials management in the construction industry. Results and findings will be discussed in the next sections.

have been discussed to identify the current state of research as summarised in Table 1.

Table 1: Development of Materials Managemen

\begin{tabular}{|c|c|c|c|c|c|c|c|}
\hline No & $\begin{array}{l}\text { Autho } \\
\mathbf{r}\end{array}$ & Year & Objective & Topic & Project type & Limitation & Output \\
\hline 1 & [13] & 1994 & $\begin{array}{l}\text { A perspective of } \\
\text { materials management } \\
\text { practices in a fast } \\
\text { developing economy: the } \\
\text { case of Malaysia. }\end{array}$ & $\begin{array}{c}\text { Develop a materials management } \\
\text { flow chart to facilitate local } \\
\text { contractors in managing } \\
\text { materials. }\end{array}$ & $\begin{array}{l}\text { General } \\
\text { construction } \\
\text { project. }\end{array}$ & $\begin{array}{l}\text { Large and } \\
\text { Medium } \\
\text { Contractors. }\end{array}$ & $\begin{array}{l}\text { Materials control } \\
\text { flow chart. }\end{array}$ \\
\hline 2 & [14] & 2008 & $\begin{array}{l}\text { An Efficient Materials } \\
\text { Management Model to } \\
\text { Improve Productivity }\end{array}$ & $\begin{array}{c}\text { A model minimizing } \\
\text { inefficiencies of site materials } \\
\text { handling was developed. }\end{array}$ & $\begin{array}{l}\text { Construction } \\
\text { building } \\
\text { projects. }\end{array}$ & $\begin{array}{c}\text { Large } \\
\text { contractors. }\end{array}$ & $\begin{array}{l}\text { Web-based model } \\
\text { for productivity } \\
\text { improvement. }\end{array}$ \\
\hline 3 & [16] & 2008 & $\begin{array}{l}\text { Improving Materials } \\
\text { Management on } \\
\text { Construction Projects }\end{array}$ & $\begin{array}{l}\text { Develop and evaluate a prototype } \\
\text { system for integrating materials } \\
\text { management and resource } \\
\text { modelling. }\end{array}$ & $\begin{array}{l}\text { Construction } \\
\text { building } \\
\text { projects. }\end{array}$ & $\begin{array}{c}\text { Large } \\
\text { contractors. }\end{array}$ & $\begin{array}{l}\text { A prototype system } \\
\text { for materials } \\
\text { management } \\
\text { improvement. } \\
\end{array}$ \\
\hline 4 & [12] & 2013 & $\begin{array}{l}\text { Examining the Effect of } \\
\text { Challenges on the } \\
\text { Effectiveness of } \\
\text { Materials Industry } \\
\text { Management in the } \\
\text { Malaysian Construction. }\end{array}$ & $\begin{array}{l}\text { The study aims to help the } \\
\text { contractors, clients, consultants } \\
\text { and all parties involved in } \\
\text { construction projects with the } \\
\text { ways of improving their } \\
\text { presentation techniques and } \\
\text { methods of materials } \\
\text { management. }\end{array}$ & $\begin{array}{l}\text { Construction } \\
\text { building } \\
\text { projects. }\end{array}$ & $\begin{array}{c}\text { Large } \\
\text { contractors. }\end{array}$ & $\begin{array}{l}\text { Challenges affecting } \\
\text { materials } \\
\text { management in } \\
\text { Penang Island } \\
\text { Malaysia. } \\
\text { (still in progress) }\end{array}$ \\
\hline
\end{tabular}




\begin{tabular}{|c|c|c|c|c|c|c|c|}
\hline No & Author & Year & Objective & Topic & Project type & Limitation & Output \\
\hline 5 & [4] & 2013 & $\begin{array}{l}\text { An Assessment of } \\
\text { Materials } \\
\text { management on } \\
\text { Building } \\
\text { Construction Sites. }\end{array}$ & $\begin{array}{l}\text { Determine the } \\
\text { method of material } \\
\text { procurement } \\
\text { practices on the } \\
\text { construction site. } \\
\text { Suggest measures } \\
\text { for } \\
\text { materials effective } \\
\text { management on } \\
\text { building } \\
\text { construction sites. }\end{array}$ & $\begin{array}{l}\text { Construction } \\
\text { building } \\
\text { projects. }\end{array}$ & $\begin{array}{l}\text { Large } \\
\text { contractors. }\end{array}$ & $\begin{array}{l}\text { Recommendation on how } \\
\text { to improve materials } \\
\text { management on site. } \\
\text { (still in progress) }\end{array}$ \\
\hline 6 & {$[6]$} & 2014 & $\begin{array}{l}\text { Materials } \\
\text { Management } \\
\text { Practices in the } \\
\text { Construction } \\
\text { Industry. }\end{array}$ & $\begin{array}{l}\text { Identify the } \\
\text { materials } \\
\text { management } \\
\text { function and } \\
\text { practices in the } \\
\text { construction } \\
\text { industry. }\end{array}$ & $\begin{array}{l}\text { Infrastructure } \\
\text { projects. }\end{array}$ & $\begin{array}{l}\text { Large } \\
\text { contractors. }\end{array}$ & $\begin{array}{l}\text { List of materials } \\
\text { management practices in } \\
\text { infrastructure } \\
\text { construction. } \\
\text { (still in progress) }\end{array}$ \\
\hline 7 & {$[15]$} & 2015 & $\begin{array}{l}\text { The Framework of } \\
\text { Improving On-Site } \\
\text { Materials Tracking } \\
\text { for } \\
\text { Management } \\
\text { Processes } \\
\text { Construction Project } \\
\text { Sites. }\end{array}$ & $\begin{array}{l}\text { Improving } \\
\text { materials } \\
\text { management. }\end{array}$ & $\begin{array}{l}\text { Construction } \\
\text { building } \\
\text { projects. }\end{array}$ & $\begin{array}{l}\text { Large } \\
\text { contractors. }\end{array}$ & $\begin{array}{l}\text { Framework for on-site } \\
\text { inventory tracking. }\end{array}$ \\
\hline 8 & {$[17]$} & 2017 & $\begin{array}{lr}\text { Influential } & \text { Factors } \\
\text { Affecting Materials } \\
\text { Management in } \\
\text { Construction Projects }\end{array}$ & $\begin{array}{l}\text { Identifying } \\
\text { influential factors } \\
\text { affecting } \\
\text { management. }\end{array}$ & $\begin{array}{l}\text { General } \\
\text { construction } \\
\text { project. }\end{array}$ & $\begin{array}{l}\text { Large } \\
\text { contractors. }\end{array}$ & $\begin{array}{l}47 \text { influential factors were } \\
\text { identified. } \\
\text { (still in progress) }\end{array}$ \\
\hline 9 & {$[18]$} & 2017 & $\begin{array}{l}\text { Factors Affecting } \\
\text { Materials } \\
\text { management on } \\
\text { Construction Sites. }\end{array}$ & $\begin{array}{l}\text { Identification of } \\
\text { factors affecting } \\
\text { materials } \\
\text { management in } \\
\text { small medium and } \\
\text { large contractors. }\end{array}$ & $\begin{array}{l}\text { General } \\
\text { construction } \\
\text { project. }\end{array}$ & $\begin{array}{l}\text { Large } \\
\text { contractors. }\end{array}$ & $\begin{array}{l}\text { Factors affecting materials } \\
\text { management } \\
\text { small/medium/large } \\
\text { contractors. } \\
\text { (still in progress) }\end{array}$ \\
\hline 10 & [21] & 2017 & $\begin{array}{l}\text { Improving } \\
\text { Construction } \\
\text { Materials } \\
\text { Management } \\
\text { Practices in } \\
\text { Construction Sites. }\end{array}$ & $\begin{array}{l}\text { Improving the } \\
\text { performance of the } \\
\text { materials } \\
\text { management } \\
\text { construction sites. }\end{array}$ & $\begin{array}{l}\text { General } \\
\text { construction } \\
\text { projects. }\end{array}$ & $\begin{array}{l}\text { Large } \\
\text { Contractors. }\end{array}$ & $\begin{array}{l}\text { Introduces appropriate } \\
\text { methods for improving } \\
\text { materials management } \\
\text { practices in the } \\
\text { construction site. } \\
\text { (still in progress) }\end{array}$ \\
\hline
\end{tabular}

The literature review was selected from the year 1994 to 2017. From the table, five (5) research projects in materials management were focusing on building projects. While four (4) focused on a general construction project and one (1) on an infrastructure project.

It is very clear that materials management plays a vital role in the construction industry regardless of the contractors' classification (whether micro, small, medium, or large). The literature review also proved that large contractors are effectively implementing materials management in the various stages of a project and tend to integrate materials into the early stages of project planning [18], [20] due to the availability of resources. In addition, the table also clearly shows that most of materials management studies in the industry have been devoted to large construction companies. A study of materials management in small and medium contractors is crucial because small and medium contractors are the backbone of the country's economy and contribute positively to gross domestic products worldwide [23]. Moreover, small and medium contractors are responsible for more than $90 \%$ of the construction activities in the construction industry [1].

\section{Conclusion and further work}

Materials management has become a critical component of successful project implementations in the construction industry. Over the past years, large contractors spent more than $60 \%$ of the project cost on materials and equipment, yet the literature shows little improvement in the management of those materials over that time. Not only that, little attention has been given to making improvements among the small and medium contractors.

Further research will focus on issues and

\footnotetext{
* Corresponding author: Ngorgracethiik@Gmail.com
} 
improvement that could be made for small and medium contractors in the industry

\section{References}

1. CIDB, Construction Industry Transformation Programme (CITP) 2016-2020 (2016)

2. D. J. Robby, Malaysia and Construction Industry Present, Res. Gate (2016)

3. H. Nasir, Best Productivity Practices Implementation Index - Industrial Projects, (2013)

4. C. Ayegba, An Assessment of Material Management on Building Construction Sites, vol. 3 no. 5, pp. 18-23, (2013)

5. N. N. Dawood, Materials management systems for the construction industry, pp. 735-743 (1994)

6. C. H. Caldas, C. L. Menches, P. M. Reyes, L. Navarro, and D. M. Vargas, Materials Management Practices in the Construction Industry, Pract. Period. Struct. Des. Constr., vol. 20, no. 3, pp. 1-8, (2014)

7. H. R. Thomas and S. R. Sanders, No Title Impact Of Material Management On Productivity - A Case Study, vol. 115 no. 3 pp. 370-384 (1990)

8. L. C. Bell and G. Stukhart, Attributes of Materials Management Systems, J. Constr. Eng. Manag., vol. 112 no. 1 pp. 14-21, (1986)

9. M. P. N. Mane, A. K. Gupta, and P. D. B. Desai, A Review Paper on Onsite Material Management for Construction Projects, no. 2 pp. 1288-1290, (2017)

10. P. F. Kaming, G. D. Holt, S. T. Kometa, and P. O. Olomolaiye, Severity diagnosis of productivity problems--a reliability analysis, Int. J. Proj. Manag., vol. 16 no. 2 pp. 107-113, (1998)

11. N. B. Kasim, Improving materials management on construction projects, (2008)

12. S. Yazdani Mehr and A. Omran, Examining the challenges affect on the effectiveness of materials management in the Malaysian construction industry, Int. J. Acad. Res., vol. 5 no. 2 pp. 56-63 (2013)

13. H. Abdul-Rahman and M. N. Alidrisyi, A Perspective of Material Management Practices in A Fast Developing Economy: The Case of Malaysia, Constr. Manag. Econ. vol. 12 no. 5 pp. 413-422 (1994)

14. G. Zhang and J. Ruwanpura, an Efficient Materials Management Model To, Jt. CIB Int. Symp. W055, W065, W089, W118, TG76, TG78, TG81 TG84, (2008)

15. S. R. B. LIWAN, The framework of improving onsite materials tracking for inventory management process in construction projects, pp. 1-161, (2015)

16. N. Kasim, R. E. Management, and U. T. Hussein, 'Improving materials management practices in construction projects', Internotionui Synrposium Dev. Econ., vol. 11 no. 1 pp. 356-369 (2008)

17. Z. M. Jusoh and N. Kasim, 'Influential Factors Affecting Materials Management in Construction Projects', Manag. Prod. Eng. Rev., vol. 8 no. 4 pp. 82-90 (2017)
18. V. Kulkarni, R. Sharma, M. Hote, and M. E. Civil, 'Factors affecting material management on construction site', J. Eng. Technol., vol. 4 no. 1 pp. 474-478 (2017)

19. J. Plemmons and L. Bell, 'Measuring effectiveness of materials management process', J. Manag. Eng., vol. 11 no. 6 pp. 26-32 (1995)

20. M. Al-Khalil, S. Assaf, T. Al-Faraj, and A. AlDarweesh, Measuring Effectiveness of Materials Management for Industrial Projects, J. Manag. Eng., vol. 20 pp. 82-87 (2004)

21. Fuad Hassan Ahmed, Improving Construction Materials Management Practices in Construction Sites, (2017)

22. M. Saunders, P. Lewis, and a. Thornhill, Research Methods for Business Students, vol. 5 (2009)

23. E. M. Kamal and R. Flanagan, Key Characteristics of Rural Construction SMEs, J. Constr. Dev. Ctries., vol. 19 no. 2 pp. 1-13 (2014) 